\title{
Baicalein inhibits the growth of oral squamous cell carcinoma cells by downregulating the expression of transcription factor Sp1
}

\author{
ZILONG GAO ${ }^{1}$, YAQIAN ZHANG ${ }^{2}$, HENG ZHOU ${ }^{3}$ and JUAN LV ${ }^{1}$ \\ ${ }^{1}$ Dongfeng Stomatological Hospital, Hubei University of Medicine, Shiyan, Hubei 442000; \\ ${ }^{2}$ Department of Pathogen Biology, College of Basic Medical Sciences; ${ }^{3}$ Department of Pathology, \\ Renmin Hospital, Wuhan University, Wuhan, Hubei 430060, P.R. China
}

Received March 18, 2019; Accepted August 29, 2019

DOI: $10.3892 /$ ijo.2019.4894

\begin{abstract}
Oral squamous cell carcinoma (OSCC), the most common malignancy of the oral cavity, accounts for $>90 \%$ of all diagnosed oral cancer cases. Baicalein, a naturally derived compound, has been shown to alter p65 and the nuclear factor (NF) $-\kappa B$ pathway, thus exerting cytotoxic effects on various tumor cell types. However, the mechanism of action of baicalein in OSCC has not been fully elucidated. In the present study, the proliferation of OSCC cells treated with baicalein was examined using a CCK-8 assay. The effects of baicalein on the cell cycle and apoptosis of OSCC cells were determined by flow cytometric analyses. The expression of specificity protein 1 (Sp1), p65 and p50 at the mRNA and protein levels was determined by reverse transcription-quantitative PCR and western blot analysis, respectively. The results of the present study demonstrated that baicalein suppresses the proliferation of OSCC cell lines in vivo and in vitro. Baicalein also induced apoptosis of OSCC cells and arrested the cell cycle at the G0/G1 phase. Baicalein inhibited the expression of Sp1, p65 and p50 by downregulating the relative mRNA levels. Baicalein reduced the activity of NF- $\kappa \mathrm{B}$ in OSCC cells. Knockdown of $\mathrm{Sp} 1$ also resulted in reduced expression of $\mathrm{p} 65$ and p50. In addition, Sp1 silencing enhanced the effects of baicalein. In conclusion, the present study demonstrated that baicalein suppresses the growth of OSCC cells through an $\mathrm{Sp} 1 / \mathrm{NF}-\kappa \mathrm{B}-$ dependent mechanism.
\end{abstract}

Correspondence to: Dr Juan Lv, Dongfeng Stomatological Hospital, Hubei University of Medicine, Shiyan, Hubei 442000, P.R. China

E-mail: 1vjuan534@sina.com

Dr Heng Zhou, Department of Pathology, Renmin Hospital, Wuhan University, Wuhan, Hubei 430060, P.R. China

E-mail: hengzhou117@163.com

Key words: oral squamous cell carcinoma, specificity protein 1, baicalein, nuclear factor- $\kappa \mathrm{B}, \mathrm{p} 65$

\section{Introduction}

There were an estimated $\sim 34,000$ new cases of oral cancer and 7,000 oral cancer-related deaths in the United States in 2018 (1). Oral squamous cell carcinoma (OSCC), the most common malignancy of the oral cavity, accounts for $>90 \%$ of all diagnosed oral cancers (2). Although the 5-year survival rate of OSCC has increased from 56 to $62 \%$ due to improvements in treatment, including surgery, radiation and chemotherapy (3), the development of new therapeutic strategies is important.

Baicalein, a bioactive flavonoid present in the dry root of Scutellariae Radix (Huang Qin), has been reported to have effects on various malignancies, including lung, breast, hepatocellular, pancreatic and gastric cancer (4-8). In addition, baicalein induces various biological molecular activities by blocking tumor-associated signaling pathways (9). For example, baicalein suppresses the expression of superoxide dismutase and hypoxia-inducible factor- $1 \alpha$, and inhibits lung carcinoma cell proliferation and metastasis (10). Baicalein was previously found to induce apoptosis of pancreatic cancer cells via a myeloid cell leukemia 1-dependent pathway (11). Baicalein also induces apoptosis and autophagy of breast cancer cells by suppressing the phosphatidylinositol 3 kinase/protein kinase B pathway in vivo and in vitro (12). Importantly, baicalein does not appear to cause mutagenesis in normal cells, which is the major side effect of conventional anticancer drugs $(13,14)$. Previous studies have revealed that baicalein is an effective molecular anticarcinogenic agent against oral cancer $(15,16)$, and that it induces autophagy of oral cancer cells by promoting reactive oxygen species-dependent signaling pathways and arresting the proliferation of oral cancer cells in the G0/G1 phase by enhancing the degradation of cyclin D1 and activating aryl hydrocarbon receptor to decrease retinoblastoma (Rb) phosphorylation $(15,16)$.

Specificity protein $1(\mathrm{Sp} 1)$ is a zinc finger-type transcription factor with a guanine-cytosine-rich binding sequence in the gene promoter (17). Sp1 is involved in multiple aspects of tumor cell behavior, including growth, survival, angiogenesis and apoptosis (18-20). Sp1 expression and activation are considered to be associated with human cancer development and progression (21). Lines of evidence have indicated that targeting Sp1 and its downstream target proteins may be a potential treatment strategy for oral cancer (22). Our previous 
study suggested that baicalein inhibits the expression of Sp1 and the downstream protein Epstein-Barr virus nuclear antigen 1 (EBNA1) and induces apoptosis of nasopharyngeal carcinoma (NPC) (23).

The present study examined the effects of baicalein on the proliferation, apoptosis and cell cycle progression of OSCC cells and xenograft tumors in vivo, and investigated the underlying mechanism.

\section{Materials and methods}

Cell lines and reagents. SCC25, CAL27 and HSC3 cells were kindly provided by Professor Bin Shi (University of Wuhan, China). All cell lines were cultured in RPMI-1640 media (HyClone; GE Healthcare Life Sciences) supplemented with $10 \%$ FBS (Gibco; Thermo Fisher Scientific, Inc.) at $37^{\circ} \mathrm{C}$ and humidified atmosphere of $5 \% \mathrm{CO}_{2}$. Baicalein (Sigma-Aldrich; Merck KGaA) was dissolved in DMSO at $100 \mathrm{mM}$ as a stock solution, and diluted to a working concentration $(1 \mathrm{mM})$ with PBS prior to use. For the in vivo xenograft studies, baicalein was dissolved in a solution containing $80 \%$ PBS and $20 \%$ DMSO.

Plasmid. For the construction of the Sp1 expression plasmid, the full-length cDNA was amplified and inserted into the EcoRI/XhoI sites of the pcDNA3.1 vector (Invitrogen; Thermo Fisher Scientific, Inc.). The primers for Sp1 were as follows: Forward, 5'-CCAAAATGCGATCGCATGAGCGACCAA GATCAC-3' and reverse, 5'-GAATCAAGTTTAAACTCA GAAGCCATTGCCACT-3'. The NF- $\mathrm{B}$ activity plasmid was a gift from Professor H. Shu (University of Wuhan). The PRL-TK plasmid was a gift from Professor D. Guo.

Cell viability assay. SCC25, CAL27 and HSC3 cells $\left(1 \times 10^{4}\right.$ cells/well) were seeded in 96-well plates and treated with DMSO control $(0.01 \%)$ or increasing concentrations of baicalein $(30,60$ and $120 \mu \mathrm{M})$ at $37^{\circ} \mathrm{C}$. After incubation for 24 , 48 and $72 \mathrm{~h}$, the cells were treated with $10 \mu \mathrm{l}$ Cell Counting Kit- 8 reagent (Dojindo Molecular Technologies, Inc.) and the plates were incubated at $37^{\circ} \mathrm{C}$ for $1 \mathrm{~h}$ in the dark. The optical density was measured at an absorbance of $450 \mathrm{~nm}$ using an ELx800 microimmunoanalyser (BioTek Instruments, Inc.).

Cell cycle analysis. SCC25, CAL27 and HSC3 cells were seeded in 6-well plates and treated with DMSO $(0.01 \%)$ or baicalein $(60 \mu \mathrm{M})$ at $37^{\circ} \mathrm{C}$ for $24 \mathrm{~h}$. The process was performed as described previously (24). Briefly, cells were digested and washed twice with cold PBS solution, and then resuspended in cold $75 \%$ ethanol. After fixation at $-20^{\circ} \mathrm{C}$ for $24 \mathrm{~h}$, cells were collected and resuspended in $0.5 \mathrm{ml}$ cold PBS. Cells were mixed with reagent $\mathrm{A}$ [Multisciences (Lianke) Biotech Co. Ltd.] and incubated at $4^{\circ} \mathrm{C}$ for $30 \mathrm{~min}$ in the dark. Cell cycle analysis was performed using a Beckman Coulter system (EPICS Altra II; Beckman Coulter, Inc.).

Cell apoptosis analysis. Apoptosis of OSCC cells was detected using the Annexin V-FITC/propidium iodide (PI) apoptosis detection kit [Multisciences (Lianke) Biotech Co., Ltd.], as instructed by the manufacturer. Briefly, following treatment with baicalein $(15,30$ and $60 \mu \mathrm{M})$ at $37^{\circ} \mathrm{C}$ for $24 \mathrm{~h}$, cells were digested. After three washes with PBS, $2 \times 10^{5}$ cells were resuspended in $500 \mu \mathrm{l} 1 \mathrm{X}$ binding buffer, followed by addition of $5 \mu \mathrm{l}$ Annexin V-FITC and $10 \mu \mathrm{l} \mathrm{PI}$, and incubated for $30 \mathrm{~min}$ at $20-28^{\circ} \mathrm{C}$ in the dark. Cell apoptosis was immediately analyzed using a Beckman Coulter system (EPICS Altra II; Beckman Coulter, Inc.).

Western blot analysis. At $4 \mathrm{~h}$ post-transfection, SCC25, CAL27 and HSC3 cells were washed with PBS and treated with DMSO $(0.01 \%)$ or baicalein $(30$ or $60 \mu \mathrm{M})$. After $48 \mathrm{~h}$ of incubation, cells were harvested and dissolved in RIPA lysis buffer (Beyotime Institute of Biotechnology) with $0.5 \%$ cocktail protease inhibitor (Roche Diagnostics). Following incubation on ice for $10 \mathrm{~min}$, cell lysates were collected and sonicated for $20 \mathrm{sec}$. Protein concentration was determined using a BCA assay (BioRad Laboratories, Inc.). Quantified proteins were mixed with $5 \mathrm{X}$ loading buffer $[250 \mathrm{nM}$ Tris-Hcl (pH 6.8), 0.5\% bromophenol blue, 50\% glycerol, 10\% SDS and $5 \% \beta$-mercaptoethanol] and boiled for $5 \mathrm{~min}$. The lysates were separated by SDS-PAGE on $10 \%$ gels, then subjected to immunoblot analyses. The primary antibodies used were as follows: GAPDH (cat. no. 10494-1-AP; 1:5,000; ProteinTech Group, Inc.); cleaved caspase-3 (cat. no. 9664; 1:1,000; Cell Signaling Technology, Inc.); caspase-9 polyclonal antibody (cat. no. A2636; 1:1,000; ABclonal Biotech Co., Ltd.); cleaved poly(ADP-ribose) polymerase (PARP-1; cat. no. sc-56196; 1:500; Santa Cruz Biotechnology, Inc.); Sp1 (cat. no. 9389; 1:1,000; Cell Signaling Technology, Inc.); p65 (cat. no. ab16502; 1:1,500; Abcam); p-p65 (cat. no. ab86299; 1:1,000; Abcam); and p50 (cat. no. 3035; 1:1,000; Cell Signaling Technology, Inc.). Western blot gray values were determined by ImageJ software (National Institutes of Health).

Reverse transcription-quantitative PCR (RT-qPCR). SCC25, CAL27 and HSC3 cells $\left(1 \times 10^{5}\right)$ were placed in 24-well plates. After attaching to the wells, the cells were washed with PBS and treated with DMSO $(0.01 \%)$ or baicalein $(30$ or $60 \mu \mathrm{M})$. After incubation at $37^{\circ} \mathrm{C}$ for $24 \mathrm{~h}$, total RNA was extracted by using TRIzol reagent (Thermo Fisher Scientific, Inc.) according to the manufacturer's instructions. Subsequently, cDNA was synthesized from total RNAs $(1 \mu \mathrm{g})$ using an RT kit (Takara Bio, Inc.) according to the manufacturer's instructions. The mRNA expression levels of Sp1, p65 and p50 were quantified using the CFX96 Real-Time PCR Detection System with an SYBR Premix Ex Taq kit (Takara Bio, Inc.). The primers were as follows: p65, forward 5'-CGGGATGGCTTCTAT GAGG-3' and reverse 5'-CTCCAGGTCCCGCTTCTT-3'; p50, forward 5'-ACCCTGACCTTGCCTATTTG-3' and reverse 5'-AGCTCTTTTTCCCGATCTCC-3'; Sp1, forward 5'-ATG GGGGCAATGGTAATGGTGG-3' and reverse 5'-TCAGAA CTTGCTGGTTCTGTAAG-3'; GAPDH, forward 5'-GGT GGCTTCTGACTTCAACA-3' and reverse 5'-GTTGCTGTA GCCAAATTCGTTGT-3'. The mRNA levels were normalized to GAPDH as the reference gene.

Cell transfection. A specific short hairpin RNA (shRNA) targeting Sp1 (5'-GCATAT TTGCCACATCCAAGG-3', Sp1-Homo-1828; GenePharma, Co., Ltd.) or a non-specific control (NC; 5'-TTCTCCGAACGTGTCACGT-3'; Shanghai GenePharma Co., Ltd.) were transfected to cells using X-treme 

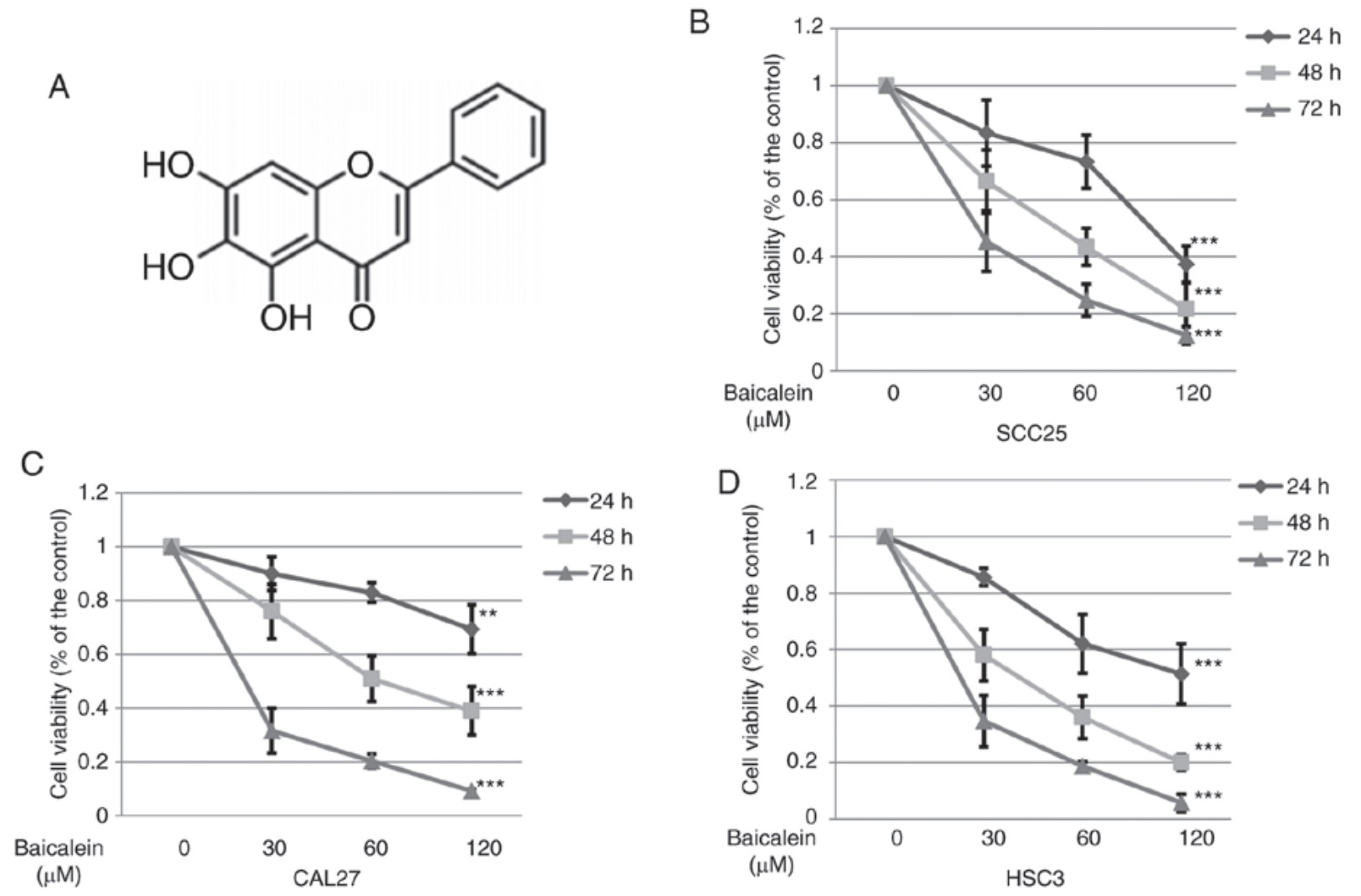

Figure 1. Baicalein inhibits the proliferation of oral squamous cell carcinoma cells. (A) Chemical structure of baicalein (5,6,7-trihydroxyflavone). (B) SCC25, (C) CAL27 and (D) HSC3 cells were treated with $0.01 \%$ DMSO or a series of increasing baicalein concentrations (30, 60 and $120 \mu \mathrm{M})$ for 24,48 and $72 \mathrm{~h}$, and the cell viability was detected using a CCK- 8 assay. All the experiments were repeated three times. The values shown are the mean \pm standard deviation of 3 independent experiments carried out in triplicate. One-way ANOVA was used to compare the experimental and control groups. ${ }^{*} \mathrm{P}<0.05$, ${ }^{* *} \mathrm{P}<0.01$ and ${ }^{* * * *} \mathrm{P}<0.001$.

GENE HP DNA Transfection Reagent (Roche Diagnostics; 40 pmol for each shRNA) according to the manufacturer's instructions. PcDNA3.1-Sp1 or pcDNA3.1 (vehicle control) was transfected to cells using X-treme GENE HP DNA Transfection Reagent. At 4 h post-transfection, cells (SCC25) were washed with PBS and treated with DMSO $(0.01 \%)$ or baicalein $(60 \mu \mathrm{M})$. After $48 \mathrm{~h}$, the cells were harvested for western blot analysis. For RT-qPCR, total RNA was collected after 12 or $24 \mathrm{~h}$ of incubation. For the dual luciferase reporter assay, cells were harvested after 24 or $48 \mathrm{~h}$ of incubation.

Dual luciferase reporter assay. Cells $\left(1 \times 10^{5}\right)$ were placed in 24 -well plates and incubated at $37^{\circ} \mathrm{C}$ overnight prior to transfection. Plasmids were co-transfected into the cells for $24 \mathrm{~h}$. After treatment with baicalein or control for $24 \mathrm{~h}$, cells were collected and analyzed using the Dual Luciferase Reporter Assay system (Promega Corporation) as previously described (25).

Animal studies. The Medical Ethics Committee of Wuhan University approved the animal experimental protocols in the present study (G201725). A total of $10 \mathrm{BALB} / \mathrm{c}$ nude mice were obtained from the Animal Biosafety Level-III Laboratory of Wuhan University and housed in a specific pathogen-free environment. SCC 25 cells $\left(5 \times 10^{6} / 100 \mu 1\right)$ were subcutaneously injected into the flanks of the mice when they were 6-7 weeks old. When the tumors became macroscopically visible
( $\sim 7$ days), the mice were randomly divided into two groups ( $n=5 /$ group). The control group mice were injected with PBS (0.01\% DMSO) and baicalein group mice were injected with baicalein $(30 \mathrm{mg} / \mathrm{kg}$, three times a week). The mice were sacrificed after 21 days of treatment. The mouse weight and tumor size were measured. Tumor volume was calculated as $0.5 \mathrm{x}$ length $\mathrm{x}$ width ${ }^{2}$. Tissue samples were fixed in $10 \%$ neutral buffered formalin, embedded in paraffin and cut into $3-\mu \mathrm{m}$ sections).

Immunohistochemical analysis. Immunohistochemistry was performed using antibodies against Sp1 (cat. no. 9389; 1:1,000; Cell Signaling Technology, Inc.), p65 (cat. no. ab16502; 1:1,500; Abcam) and cleaved caspase-3 (cat. no. 9664; 1:1,000; Cell Signaling Technology, Inc.) according to the manufacturer's instructions. The process was performed as described previously (24). Briefly, after deparaffinization, the tissue sections were boiled in citric acid ( $\mathrm{pH} \mathrm{6.0)} \mathrm{for} 20 \mathrm{~min}$ and immersed in $3 \% \mathrm{H}_{2} \mathrm{O}_{2}$ for $10 \mathrm{~min}$ to quench the endogenous peroxidase activity. After blocking in goat serum for $1 \mathrm{~h}$ at $20-28^{\circ} \mathrm{C}$, the tissue sections were incubated with primary antibodies overnight at $4^{\circ} \mathrm{C}$. After washing, the tissue sections were incubated with secondary antibody MaxVision $^{\mathrm{TM}}$ Kits; MaxVision Biosciences, Inc.) conjugated to horseradish peroxidase. Subsequently, the tissue sections were incubated with diaminobenzidine for $1 \mathrm{~min}$ and lightly counterstained with hematoxylin. 

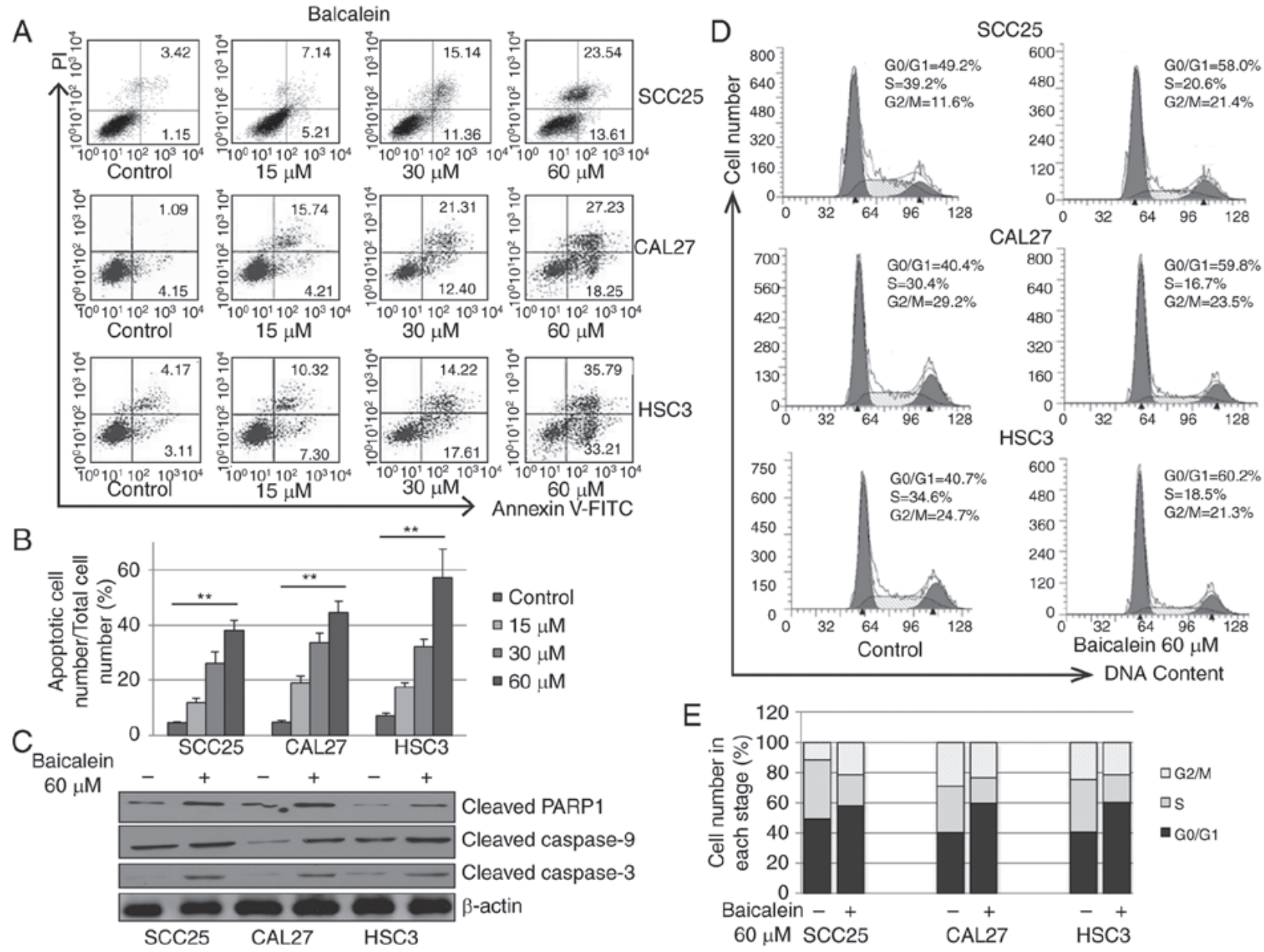

Figure 2. Baicalein arrests the cell cycle and induces apoptosis of oral squamous cell carcinoma cells. (A) SCC25, CAL27 and HSC 3 cells were treated with $0.01 \%$ DMSO or baicalein $(15,30$ and $60 \mu \mathrm{M})$ for $24 \mathrm{~h}$. Apoptosis analysis was performed by flow cytometry. (B) Apoptotic cell distribution quantification. (C) Expression of apoptosis-related proteins was determined by western blotting. (D) SCC25, CAL27 and HSC3 cells were treated with $0.01 \%$ DMSO or baicalein $(60 \mu \mathrm{M})$ for $24 \mathrm{~h}$. Cell cycle analysis was performed by flow cytometry. (E) Cell cycle distribution was quantified. All the experiments were repeated three times. The values shown are the mean \pm standard deviation of 3 independent experiments carried out in triplicate. One-way ANOVA was used to compare experimental and control groups. ${ }^{*} \mathrm{P}<0.05,{ }^{* *} \mathrm{P}<0.01$ and ${ }^{* * *} \mathrm{P}<0.001$.

Statisticalanalysis. Data are presented as the mean \pm standard deviation of three independent experiments. For the comparison of two groups, Student's t-test was selected. For the comparison of multiple groups, one-way ANOVA followed by the Newman-Keuls post hoc test was carried out. All statistical data were analyzed by using GraphPad Prism for Windows, version 5.0 (GraphPad Software, Inc.). $\mathrm{P}<0.05$ was considered to indicate a statistically significant difference.

\section{Results}

Baicalein effectively suppresses the proliferation of OSCC cells. To determine whether baicalein decreases the viability of OSCC cells, SCC25, CAL27 and HSC 3 cells were treated with varying doses of baicalein and for different durations. The chemical structure of baicalein (5,6,7-trihydroxyflavone) is shown in Fig. 1A. Baicalein significantly $(\mathrm{P}<0.05)$ reduced the viability of SCC25, CAL27 and HSC 3 cells compared with cells treated with DMSO control (Fig. 1B-D). These results suggest that baicalein effectively inhibits the proliferation of different OSCC cell lines.
Baicalein induces apoptosis in OSCC cells. To examine the apoptotic effect exerted by baicalein on OSCC cells, SCC25, CAL27 and HSC 3 cells were treated with increasing doses of baicalein for $24 \mathrm{~h}$. As shown in Fig. 2A and B, baicalein significantly induced apoptosis of SCC25, CAL27 and HSC3 cells. To further assess stimulation of the apoptotic pathway, expression of several apoptosis-associated proteins was detected by western blot analysis. Baicalein increased the protein levels of cleaved caspase-9, cleaved caspase-3 and cleaved PARP-1 in SCC25, CAL27 and HSC3 cells (Fig. 2C), suggesting that baicalein induces OSCC cell apoptosis via the mitochondrial apoptotic pathway.

Baicalein arrests the cell cycle in the G0/G1 phase. To determine whether baicalein affects the cell cycle, SCC25, CAL27 and $\mathrm{HSC} 3$ cells were treated with vehicle control $(0.01 \%$ DMSO) or baicalein $(60 \mu \mathrm{M})$ for $24 \mathrm{~h}$. The distribution of cells in different cell cycle phases was analyzed by flow cytometry. As shown in Fig. 2D and E, baicalein treatment induced cell cycle arrest in the G0/G1 phase. The fraction of SCC25, CAL27 and HSC 3 cells in the G0/G1 phase was increased by $18.8,29.4$ and $19.5 \%$, respectively, when treated with baicalein 
A
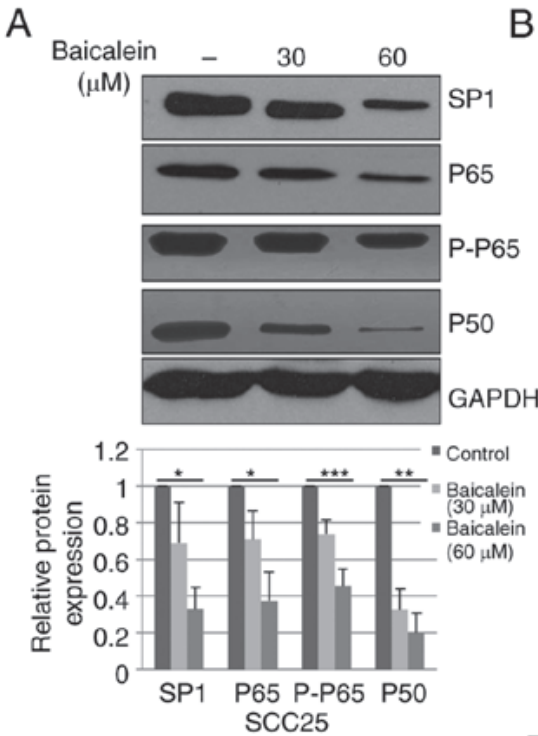

D

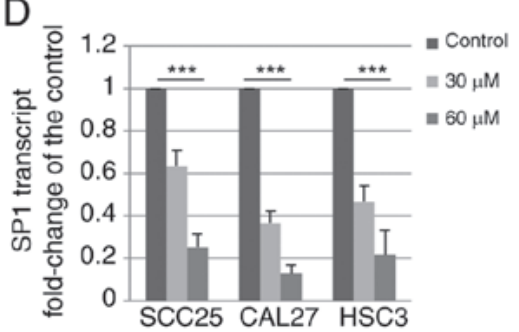

B
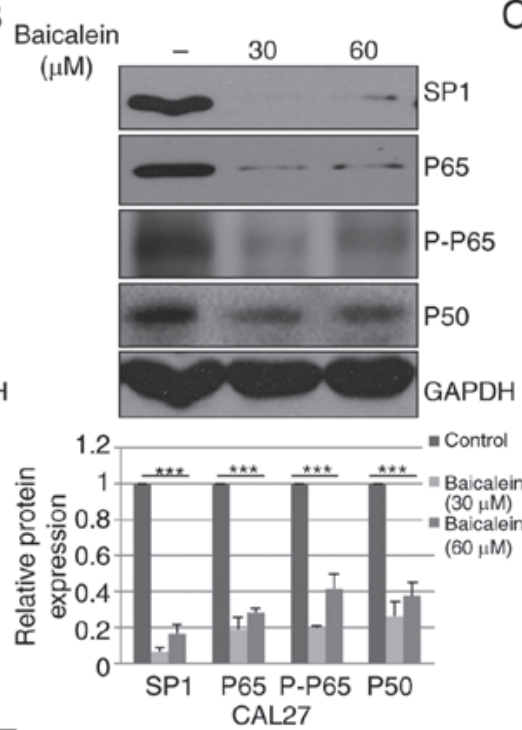

$\mathrm{E}$

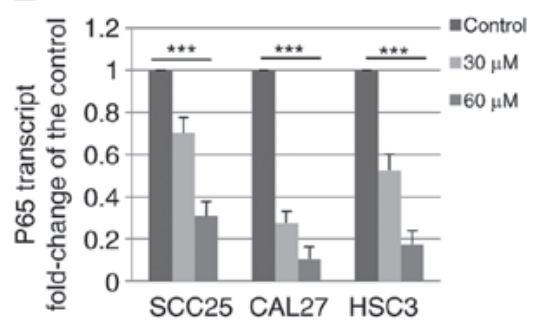

C Baicalein

$(\mu \mathrm{M})$

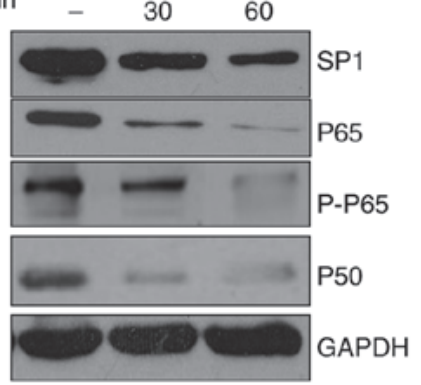

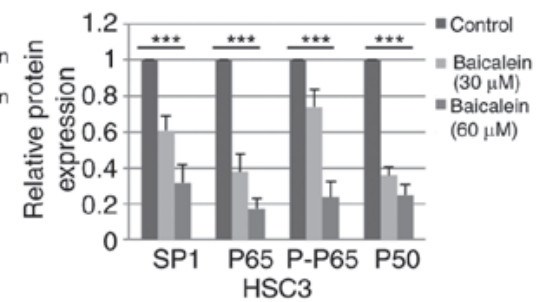

$\mathrm{F}$

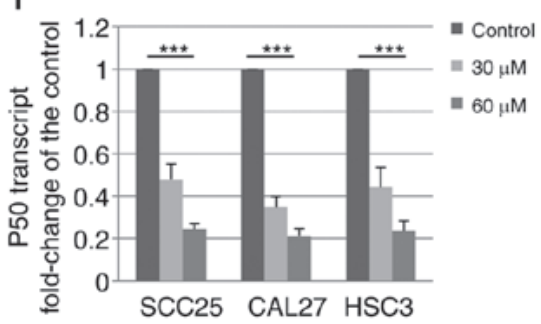

Figure 3. Baicalein inhibits the expression of Sp1, p65 and p50 in oral squamous cell carcinoma cell lines. (A) SCC25, (B) CAL27 and (C) HSC3 cells were treated with $0.01 \%$ DMSO or baicalein $(30$ and $60 \mu \mathrm{M})$ for $48 \mathrm{~h}$. The expression of Sp1, p65, p-p65 and p50 was measured by immunoblot analysis as indicated. SCC25, CAL27 and HSC3 cells were treated with 0.01\% DMSO or baicalein (30 and $60 \mu \mathrm{M})$ for 24 h. The mRNA levels of (D) Sp1, (E) p65 and (F) p50 were examined by reverse transcription-quantitative PCR analysis. All the experiments were repeated three times. The values shown are the mean \pm standard deviation of 3 independent experiments carried out in triplicate. One-way ANOVA was used to compare experimental and control groups. ${ }^{*}<0.05$, ${ }^{* *} \mathrm{P}<0.01$ and ${ }^{* * *} \mathrm{P}<0.001$. Sp1, specificity protein 1 .

$(60 \mu \mathrm{M})$. These results demonstrated that baicalein reduces the proliferation of OSCC cells by causing G0/G1 cell cycle arrest.

Baicalein decreases the expression of Sp1, p65 and p50. To determine whether baicalein alters the expression of $\mathrm{Sp} 1$ in OSCC cells, three different OSCC cell lines (SCC25, CAL27 and HSC3) were treated with DMSO control or baicalein. As shown in Fig. 3A-C, baicalein significantly $(\mathrm{P}<0.05)$ decreased Sp1 expression in SCC25, CAL27 and HSC3 cells. Sp1 has been previously demonstrated to be a transcription factor that regulates the expression of p65 and p50 (26). Therefore, the expression of p65 and p50 was measured, and the levels of p65, p-p65 and p50 were found to be decreased following treatment with baicalein (Fig. 3A-C).

The observed decrease in protein expression may be due to reduced mRNA levels; therefore, the effects of baicalein on Sp1 were also analyzed at the transcriptional level. SCC25, CAL27 and HSC3 were treated with DMSO control or baicalein, and total RNA was collected and subjected to RT-qPCR analysis. The mRNA expression of Sp1 in SCC25, CAL27 and HSC3 cells was found to be decreased by 75.7, 87.0 and $78.8 \%$, respectively, compared with controls at $48 \mathrm{~h}$ (Fig. 3D). Additionally, the mRNA levels of p65 and p50 were analyzed. As shown in Fig. 3E and F, the mRNA levels of p65 and p50 were significantly decreased following treatment with baicalein. These results suggest that baicalein decreases the expression of Sp1, p65 and p50 in OSCC cell lines by reducing the mRNA expression.

Baicalein decreases $N F-\kappa B$ activity in OSCC cells. The reduced expression of p65 and p50 may lead to suppression of the $\mathrm{NF}-\kappa \mathrm{B}$ pathway. To confirm this hypothesis, SCC25, CAL27 and HSC3 cells were treated with DMSO control or baicalein, and the activity of $\mathrm{NF}-\kappa \mathrm{B}$ was determined using a Dual Luciferase Reporter Assay system. As shown in Fig. 4A-C, the activity of the NF- $\kappa \mathrm{B}$ pathway was downregulated to $15.3 \%$ (SCC25), 8.6\% (CAL27) and $12.0 \%$ (HSC3) following treatment with baicalein $(60 \mu \mathrm{M})$ for $24 \mathrm{~h}$. These results suggest that baicalein markedly inhibits the activation of NF- $\kappa \mathrm{B}$ signaling in OSCC cells.

Reduced expression of Spl decreases the expression of 065 and $p 50$. To determine whether the decrease in p65 and p50 expression was associated with the expression of Sp1 in OSCC cells, SCC25 and CAL27 cells were transfected with a specific shRNA targeting Sp1. Total proteins were harvested and subjected to western blot analysis. As shown in Fig. 5A and B, silencing of Sp1 significantly reduced the expression of p65 and p50. Additionally, the mRNA levels of p65 were decreased to 44.3 and $29.3 \%$ following silencing of Sp1 in SCC25 and CAL27 cells, respectively (Fig. 5C). The mRNA levels of p50 in SCC25 and CAL27 cells with 

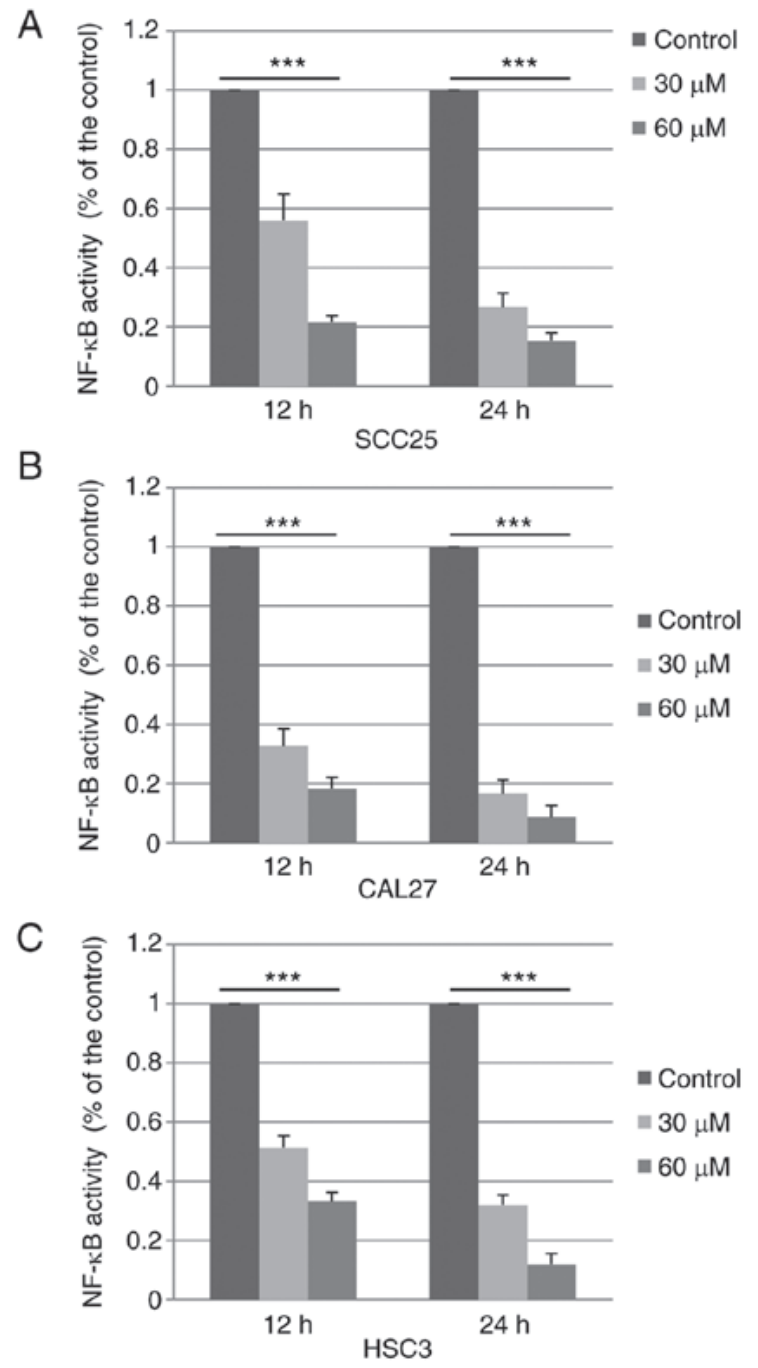

Figure 4. Baicalein inhibits the activity of the nuclear factor (NF)- $\mathrm{B}$ pathway. (A) SCC25, (B) CAL27 and (C) HSC3 cells were treated with $0.01 \%$ DMSO or baicalein $(30$ and $60 \mu \mathrm{M})$ for 12 or $48 \mathrm{~h}$. The activity of NF-kB was determined using the Dual Luciferase Reporter Assay system. All the experiments were repeated three times. The values shown are the mean \pm standard deviation of 3 independent experiments carried out in triplicate. One-way ANOVA was used to compare experimental and control groups. ${ }^{*} \mathrm{P}<0.05$, ${ }^{* *} \mathrm{P}<0.01$ and ${ }^{* * *} \mathrm{P}<0.001$.

silenced Sp1 expression were decreased to 40.3 and $25.0 \%$, respectively (Fig. 5D). These results indicate that downregulated expression of $\mathrm{Sp} 1$ reduces the expression of p65 and p50 in OSCC cells.

Downregulated expression of Spl inhibits $N F-\kappa B$ activity and the viability of OSCC cells. To determine the effect of $\mathrm{Sp} 1$ silencing on NF- $\mathrm{KB}$ activity and cell viability, SCC25 and CAL27 cells were transfected with Sp1-specific shRNA. The activity of NF- $\kappa \mathrm{B}$ was determined using the Dual Luciferase Reporter Assay system. As shown in Fig. 5E, the activity of the NF- $\mathrm{BB}$ pathway was reduced to 35 and $39.3 \%$ by Sp1-shRNA in SCC25 and CAL27 cells, respectively. The viability of SCC25 and CAL27 cells was decreased to 63.7 and $44.7 \%$, respectively, by specific Sp1-shRNA (Fig. 5F). These results indicate that silencing of $\mathrm{Sp} 1$ expression inhibits NF- $\mathrm{KB}$ activity and reduces the viability of OSCC cells.
shRNA-Spl enhances the effect of baicalein. To determine whether the effects of baicalein on NF- $\mathrm{kB}$ activity and cell viability are dependent on Sp1, SCC25 cells were transfected with shRNA-Sp1 or homo-NC, and treated with baicalein or DMSO control. As shown in Fig. 6A, combination with shRNA-Sp1 significantly enhanced the baicalein-induced suppression of Sp1, p65 and p50 expression. In addition, knockdown of Sp1 significantly contributed to the inhibitory effects of baicalein on NF-кB activity (Fig. 6B) and cell viability (Fig. 6C).

Exogenous Spl attenuates the effects of baicalein. To determine whether the effects of baicalein on cell viability are primarily caused by the reduced expression of Sp1, SCC 25 cells were transiently transfected with pcDNA3.1-Sp1 or vehicle control (pcDNA3.1). The cells were subsequently treated with DMSO or baicalein. As shown in Fig. 6D, pcDNA3.1-Sp1 significantly increased the expression of Sp1, p65 and p50. Compared with Sp1 overexpression alone, combined treatment with baicalein and pcDNA3.1-Sp1 transfection decreased the expression of Sp1, p65 and p50. As shown in Fig. 6E, the NF- $\mathrm{kB}$ activity was enhanced by 273.3 and $503.1 \%$ following transfection with pcDNA3.1-Sp1 for 12 and $24 \mathrm{~h}$, respectively. Overexpression of Sp1 attenuated the effects of baicalein on NF- $\mathrm{KB}$ activity. In addition, Sp1 overexpression increased the viability of SCC25 cells and attenuated the inhibitory effect of baicalein on cell viability (Fig. $6 \mathrm{~F}$ ). These results suggest that baicalein reduces SCC25 cell viability and NF-kB activity, which is mediated by the Sp1 pathway.

In vivo effects of baicalein on $B A L B / c$ mice inoculated with $S C C 25$ cells. To determine the effects of baicalein on OSCC in vivo, SCC25 cells were used to establish subcutaneous xenograft tumors in immune-deficient $\mathrm{BALB} / \mathrm{c}$ nude mice. The mice were administered baicalein or DMSO at 7 days after tumor cell inoculation. After treatment with baicalein or DMSO for 21 days, the mice were sacrificed and their tumors were measured. The weight of the mice was also evaluated. As shown in Fig. 7A, tumor volumes were decreased by treatment with baicalein. Additionally, there was no significant difference in the weight of the mice between the two groups (Fig. 7B). Representative images of the tumors are shown in Fig. 7C. To further elucidate the mechanism underlying the effects of baicalein on tumor growth, the expression and distribution of $\mathrm{p} 65, \mathrm{Sp} 1$ and cleaved caspase- 3 were determined by immunohistochemical examination of the tumor tissues. As shown in Fig. 7D, the expression p65 and Sp1 was stronger in the sections from the control group compared with the baicalein-treated group. Conversely, cleaved caspase-3 expression was weaker in the control group compared with that in the baicalein-treated group. These results suggest that baicalein reduces the growth of SCC25 OSCC cell xenografts in vivo.

\section{Discussion}

Accumulating evidence suggests that targeting Sp1 may be a novel therapeutic strategy for cancer treatment, as $\mathrm{Sp} 1$ is involved in tumor development, growth and metastasis $(27,28)$. $\mathrm{Sp} 1$ is overexpressed in a number of human cancer cells, including oral cancer cells (29), which suggests that Sp1 may 

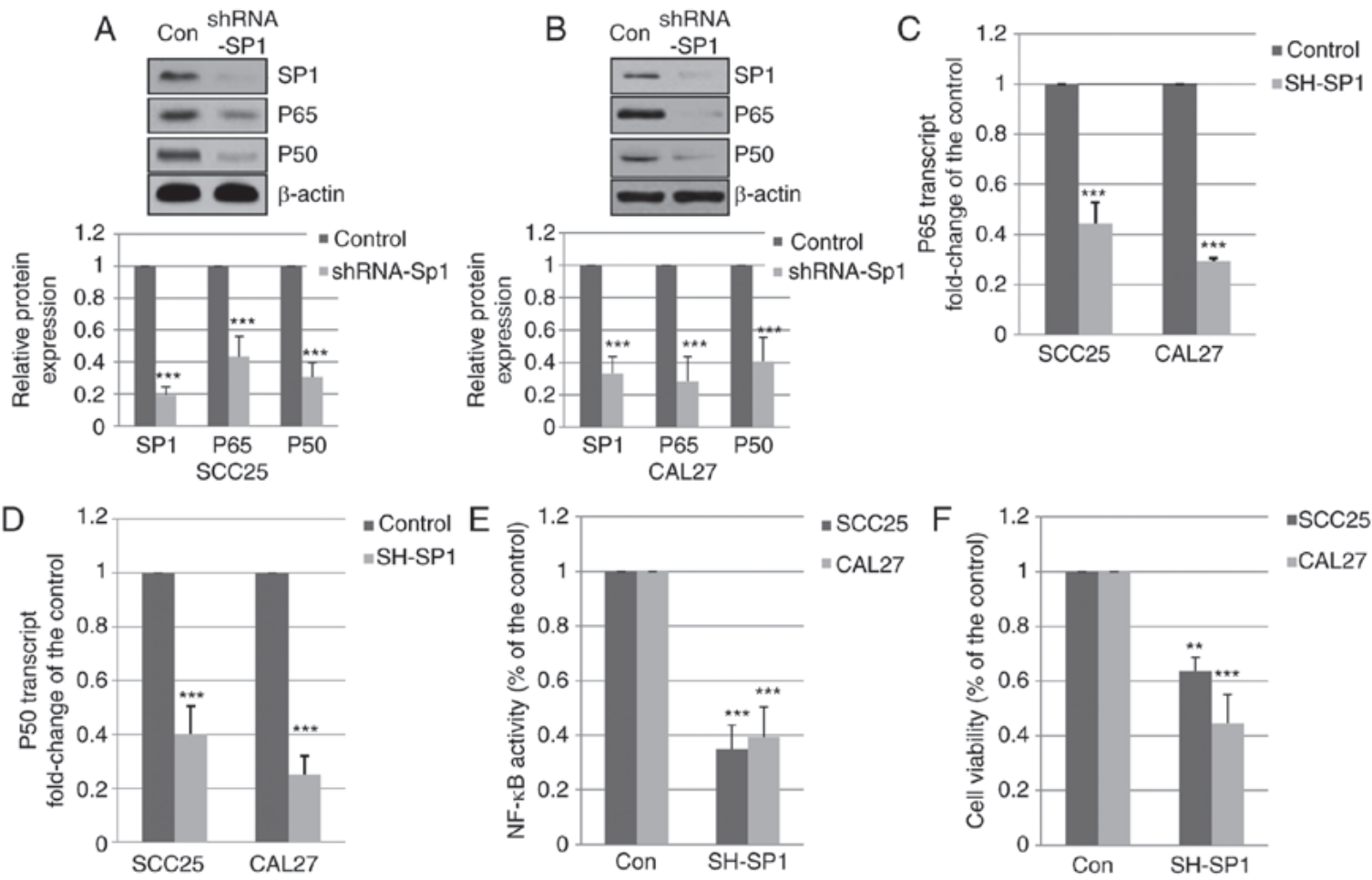

Figure 5. Inhibition of Sp1 reduces the activity of nuclear factor (NF)- $\mathrm{B}$ and the viability of oral squamous cell carcinoma cells. SCC25 and CAL27 cells were transfected with short hairpin RNA-Sp1 for $48 \mathrm{~h}$. (A and B) Total proteins were harvested and subjected to western blot analysis. The mRNA levels of (C) p65 and (D) p50 were determined by reverse transcription-quantitative PCR. (E) The activity of NF- $\mathrm{kB}$ was determined using the Dual Luciferase Reporter Assay system. (F) Cell viability was detected using a CCK-8 assay. Student's t-test was used to compare the experimental and control groups. ${ }^{*} \mathrm{P}<0.05,{ }^{* * *} \mathrm{P}<0.01$ and ${ }^{* * *} \mathrm{P}<0.001$. Sp1, specificity protein 1 .

be associated with cancer cell growth. Our previous study revealed that baicalein inhibits cancer development and expression of EBNA1 in Epstein-Barr virus-positive NPC cells via an Sp1-dependent mechanism (23); thus, it would be of interest to investigate the effects of baicalein in EBV-negative epithelial cancer cells. In the present study, baicalein, a traditional extract used in herbal medicine, effectively suppressed the proliferation of OSCC cell lines. Baicalein induced apoptosis of OSCC cells and arrested the cell cycle in the G0/G1 phase. Baicalein significantly decreased the protein and mRNA expression of Sp1, p65 and p50. Additionally, baicalein reduced $\mathrm{NF}-\kappa \mathrm{B}$ activity in OSCC cells. Furthermore, knockdown of Sp1 reduced the expression of p65 and p50, and Sp1 silencing enhanced the effects of baicalein. By contrast, overexpression of $\mathrm{Sp} 1$ attenuated the inhibitory effects of baicalein on NF- $\mathrm{KB}$ activity and cell viability. Furthermore, baicalein reduced the growth of SCC25-induced tumor xenografts in vivo.

Baicalein has been attracting increasing attention due to its cytotoxic effects on cancer cells at a low dose (30-33). Our previous study indicated that a low-toxicity dose of baicalein exerted a strong antitumor effect on NPC cells in vivo and in vitro (23). In this context, the effect of baicalein on OSCC were investigated. Baicalein has been reported to induce apoptosis via both the intrinsic and extrinsic apoptotic pathways in cancer cells. For example, baicalein treatment induces caspase- 3 and caspase- 9 activation, decreases the expression of Bcl-2 and increases the level of Bax and p53 via the ERK/p38 MAPK pathway in breast cancer (34). In addition to its pro-apoptosis effects, baicalein also regulates the cell cycle. In lung cancer cells, baicalein arrests the cell cycle in the $\mathrm{S}$ phase by downregulating the expression of cyclin A (35); however, baicalein induces G0/G1 phase arrest in other cancer types, such as prostate cancer, hepatocellular carcinoma and lung squamous cell carcinoma. Baicalein upregulates the expression of Rb, p53, p21(Cip1) and p27(Kip1), and decreases the expression of cyclin D1, cyclin E, p-Rb and CDK4, which results in an increased percentage of hepatocellular carcinoma cells in the G0/G1 phase $(36,37)$. Baicalein is also reported to reduce the growth of tumor cell-induced xenografts in animal studies, including breast, colon and pancreatic cancer xenografts $(12,38,39)$. In the present study, baicalein induced G0/G1 phase cell cycle arrest, induced apoptosis, and inhibited the growth of OSCC cells in vitro and in vivo.

Shin et al (29) reported that $\mathrm{Sp} 1$ is overexpressed in OSCC tissues compared with normal oral mucosal tissues, suggesting that Sp1 may be a valuable molecular target for the treatment of oral cancer (29). Several targeted drugs have exhibited strong cytotoxic effects against OSCC cells, including mithramycin A, an Sp1-specific inhibitor $(22,29,40)$. Our previous study revealed that baicalein reduces the expression of $\mathrm{Sp} 1$ in NPC cells (23); thus, it was hypothesized that baicalein may also decrease the expression of Sp1 in OSCC cells. As expected, the expression of $\mathrm{Sp} 1$ was reduced by baicalein treatment. Sp1 has been reported to be crucial for the transcription of the NF- $\mathrm{KB}$ subunits, $\mathrm{p} 50$ and $\mathrm{p} 65$, and involved in regulating the activity of the NF- $\kappa B$ pathway. Silencing of Sp1 was shown to reduce the expression of $\mathrm{p} 50$ and $\mathrm{p} 65$, resulting in reduced activity of the NF-kB pathway in OSCC cells. Knockdown of $\mathrm{Sp} 1$ was also found to be associated with reduced cell colony formation, consistently with our current findings (41). In 


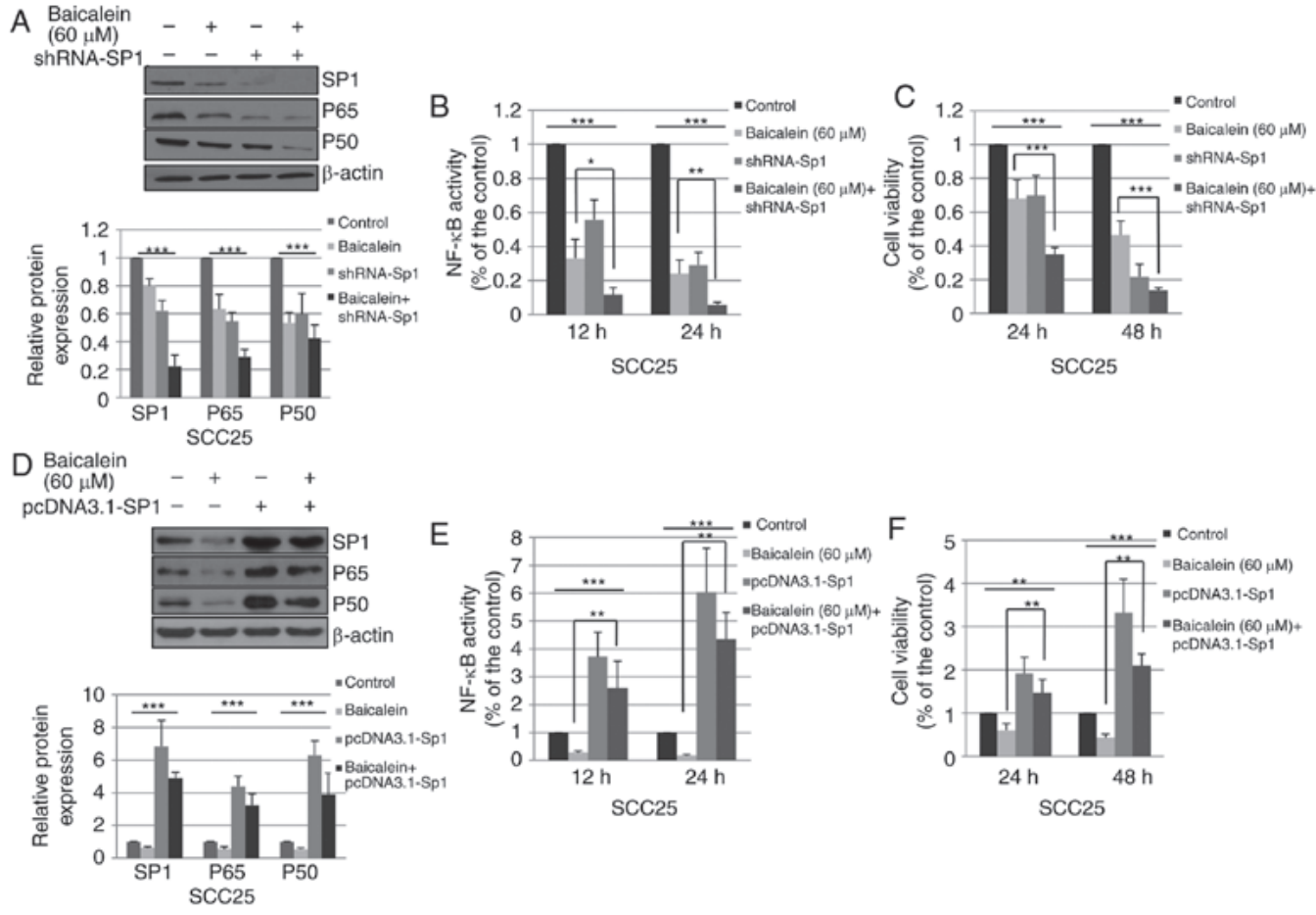

Figure 6. Baicalein inhibits nuclear factor (NF)-kB activity and viability in oral squamous cell carcinoma cells through an Sp1-dependent pathway. SCC25 cells were transfected with short hairpin RNA-Sp1 for $4 \mathrm{~h}$, and treated with baicalein $(60 \mu \mathrm{M})$ for $48 \mathrm{~h}$. (A) The expression of Sp1, p65 and p50 was detected by western blotting after $48 \mathrm{~h}$ of treatment. (B) The activity of NF- $\mathrm{kB}$ was determined using a Dual Luciferase Reporter Assay system at 12 or $24 \mathrm{~h}$. (C) Cell viability was detected using a CCK- 8 assay. SCC25 cells were transfected with pcDNA3.1-Sp1 for $4 \mathrm{~h}$ and treated with baicalein (60 $\mu \mathrm{M})$. (D) The expression of Sp1, p65 and p50 was detected by western blotting after $48 \mathrm{~h}$ of treatment. (E) The activity of NF- $\kappa \mathrm{B}$ was determined by the Dual Luciferase Reporter Assay system at 12 or $24 \mathrm{~h}$. (F) Cell viability was detected after 24 or $48 \mathrm{~h}$ of treatment using the CCK- 8 assay. All the experiments were repeated three times. The values shown are the mean \pm standard deviation of 3 independent experiments carried out in triplicate. One-way ANOVA and Newman-Keuls post hoc test were used to compare experimental and control groups. ${ }^{*} \mathrm{P}<0.05,{ }^{* * *} \mathrm{P}<0.01$ and ${ }^{* * * *} \mathrm{P}<0.001$. Sp1, specificity protein 1.
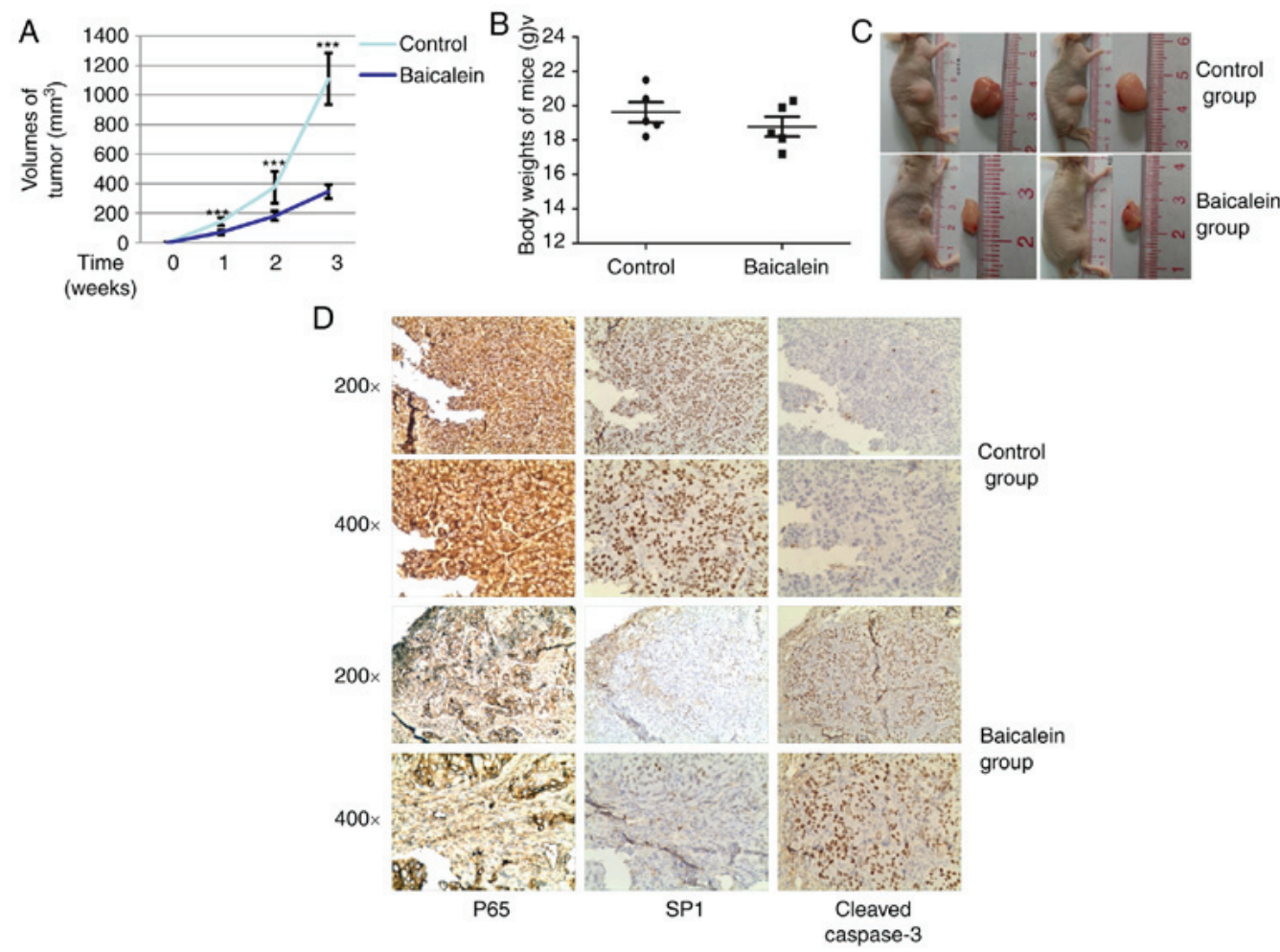

Figure 7. Baicalein inhibits the proliferation of OSCC cell-induced tumors in vivo. BALB/c nude mice with SCC25 cell-induced tumors were treated with DMSO $(0.01 \%$ ) or $30 \mathrm{mg} / \mathrm{kg}$ /day baicalein ( $\mathrm{n}=5$ per group) for 21 days. (A) Tumor volumes and (B) mouse weights were evaluated. (C) Representative photos of the dissected tumors after the mice were sacrificed. (D) The expression of $\mathrm{p} 65, \mathrm{Sp} 1$ and cleaved caspase-3 in tumor tissues was assessed by immunohistochemical analysis. Student's t-test was used to compare the experimental and control groups. ${ }^{\mathrm{P}}<0.05,{ }^{* * *} \mathrm{P}<0.01$ and ${ }^{* * * *} \mathrm{P}<0.001$. OSCC, oral squamous cell carcinoma; Sp1, specificity protein 1. 
addition, the expression of p65 and p50 in OSCC cells was decreased by baicalein treatment in the present study. Of note, decreased Sp1 expression was reduced at the mRNA level, which suggested that baicalein targets another protein in order to reduce $\mathrm{Sp} 1$ expression.

$\mathrm{NF}-\kappa \mathrm{B}$ is a transcription factor that targets anti-apoptotic genes and can promote tumor development, cell survival and malignant progression in a variety of cancer types, including OSCC (42). Matrix metalloprotease-9, which is synergistically upregulated by pro-inflammatory cytokines and growth factors in an NF- $\mathrm{NB}$-dependent manner, has been reported to be associated with nodal metastasis and reduced survival in oral cancer (43). Chemokine receptor 7 , which is associated with metastasis, is also upregulated by $N F-\kappa B$ activation (44). Thus, it may be inferred that the $\mathrm{NF}-\kappa \mathrm{B}$ pathway is a target for chemoprevention. The results of the present study suggested that $\mathrm{Sp} 1$ regulates the activity of $\mathrm{NF}-\kappa \mathrm{B}$ and the viability of OSCC cells, and attenuates the inhibitory effects induced by baicalein, which indicates that the mechanism of action of baicalein is $\mathrm{Sp} 1 / \mathrm{NF}-\kappa \mathrm{B}$-dependent. Of note, a number of studies have reported that baicalein inhibits the activity of $\mathrm{NF}-\kappa \mathrm{B}$ by reducing the expression of $\mathrm{p} 65$, with affects in various diseases and disease models, including cervical cancer, tubular-interstitial nephritis, hepatocellular carcinoma, vascular endothelial injury and Parkinson's disease (45-49). The findings of the present study demonstrated that baicalein decreases the expression of p65 and inhibits the activity of $\mathrm{NF}-\kappa \mathrm{B}$ via an Sp1-dependent mechanism.

In conclusion, the present study uncovered a novel mechanism to explain how baicalein decreases the viability and the activity of $\mathrm{NF}-\kappa \mathrm{B}$ in OSCC cells in vivo and in vitro. Knockdown of Sp1 decreased the expression of p65 and p50 in OSCC cells at the mRNA level, which resulted in reduced cell viability and reduced activity of $\mathrm{NF}-\kappa \mathrm{B}$. Baicalein also induced cell apoptosis and arrested the cell cycle in the G0/G1 phase. Notably, baicalein reduced the growth of OSCC cells by blocking an Sp1/NF-кB-dependent pathway.

\section{Acknowledgements}

The authors would like to thank Professor Bin Shi (University of Wuhan, China), Professor H. Shu (University of Wuhan, China) and Professor D. Guo (University of Wuhan, China) for supplying the cell lines and plasmids.

\section{Funding}

The present study was supported by the Nature Science Foundation for Young Scholars (grant no. 43150086), without commercial or not-for-profit sectors.

\section{Availability of data and materials}

The datasets used and/or analyzed during the present study are available from the corresponding author on reasonable request.

\section{Authors' contributions}

HZ designed the study; ZG performed the experiments; YZ and JL contributed new reagents/analytic tools; ZG analyzed the data; HZ and JL wrote the manuscript. All authors have read and approved the final version of the manuscript for publication.

\section{Ethics approval and consent to participate}

All animal experiments were approved by the ABSL-3 animal laboratory at Wuhan University.

\section{Patient consent for publication}

Not applicable.

\section{Competing interests}

The authors declare that they have no competing interests.

\section{References}

1. Siegel RL, Miller KD and Jemal A: Cancer statistics, 2018. CA Cancer J Clin 68: 7-30, 2018.

2. Sinevici N and O'Sullivan J: Oral cancer: Deregulated molecular events and their use as biomarkers. Oral Oncol 61: 12-18, 2016.

3. Braakhuis BJ, Leemans CR and Visser O: Incidence and survival trends of head and neck squamous cell carcinoma in the Netherlands between 1989 and 2011. Oral Oncol 50: 670-675, 2014.

4. Choi EO, Park C, Hwang HJ, Hong SH, Kim GY, Cho EJ, Kim WJ and Choi YH: Baicalein induces apoptosis via ROS-dependent activation of caspases in human bladder cancer 5637 cells. Int J Oncol 49: 1009-1018, 2016.

5. Du G, Han G, Zhang S, Lin H, Wu X, Wang M, Ji L, Lu L, Yu L and Liang W: Baicalin suppresses lung carcinoma and lung metastasis by SOD mimic and HIF-1alpha inhibition. Eur J Pharmacol 630: 121-130, 2010.

6. Chen M, Lai L, Li X, Zhang X, He X, Liu W, Li R, Ke X, Fu C, Huang $Z$ and Duan C: Baicalein attenuates neurological deficits and preserves blood-brain barrier integrity in a rat model of intracerebral hemorrhage. Neurochem Res 41: 3095-3102, 2016.

7. Chao JI, Su WC and Liu HF: Baicalein induces cancer cell death and proliferation retardation by the inhibition of CDC2 kinase and survivin associated with opposite role of p38 mitogen-activated protein kinase and AKT. Mol Cancer Ther 6: 3039-3048, 2007.

8. Wang L, Ling Y, Chen Y, Li CL, Feng F, You QD, Lu N and Guo QL: Flavonoid baicalein suppresses adhesion, migration and invasion of MDA-MB-231 human breast cancer cells. Cancer Lett 297: 42-48, 2010.

9. Bie B, Sun J, Guo Y, Li J, Jiang W, Yang J, Huang C and Li Z: Baicalein: A review of its anti-cancer effects and mechanisms in Hepatocellular Carcinoma. Biomed Pharmacother 93: 1285-1291, 2017.

10. Su G, Chen H and Sun X: Baicalein suppresses non small cell lung cancer cell proliferation, invasion and Notch signaling pathway. Cancer Biomark 22: 13-18, 2018.

11. Takahashi H, Chen MC, Pham H, Angst E, King JC, Park J, Brovman EY, Ishiguro H, Harris DM, Reber HA, et al: Baicalein, a component of Scutellaria baicalensis, induces apoptosis by Mcl-1 down-regulation in human pancreatic cancer cells. Biochim Biophys Acta 1813: 1465-1474, 2011.

12. Yan W, Ma X, Zhao X and Zhang S: Baicalein induces apoptosis and autophagy of breast cancer cells via inhibiting PI3K/AKT pathway in vivo and vitro. Drug Des Devel Ther 12: 3961-3972, 2018.

13. Chiu YW, Lin TH, Huang WS, Teng CY, Liou YS, Kuo WH, Lin WL, Huang HI, Tung JN, Huang CY, et al: Baicalein inhibits the migration and invasive properties of human hepatoma cells. Toxicol Appl Pharmacol 255: 316-326, 2011.

14. Mu J, Liu T, Jiang L, Wu X, Cao Y, Li M, Dong Q, Liu Y and $\mathrm{Xu} \mathrm{H}$ : The traditional chinese medicine baicalein potently inhibits gastric cancer cells. J Cancer 7: 453-461, 2016. 
15. Li B, Lu M, Jiang XX, Pan MX, Mao JW and Chen M: Inhibiting reactive oxygen species-dependent autophagy enhanced baicalein-induced apoptosis in oral squamous cell carcinoma. J Nat Med 71: 433-441, 2017

16. Cheng YH, Li LA, Lin P, Cheng LC, Hung CH, Chang NW and Lin C: Baicalein induces G1 arrest in oral cancer cells by enhancing the degradation of cyclin D1 and activating AhR to decrease Rb phosphorylation. Toxicol Appl Pharmacol 263: 360-367, 2012

17. Suske G, Bruford E and Philipsen S: Mammalian SP/KLF transcription factors: Bring in the family. Genomics 85: 551-556, 2005.

18. Shi Q, Le X, Abbruzzese JL, Peng Z, Qian CN, Tang H, Xiong Q, Wang B, Li XC and Xie K: Constitutive Spl activity is essential for differential constitutive expression of vascular endothelial growth factor in human pancreatic adenocarcinoma. Cancer Res 61: 4143-4154, 2001.

19. Abdelrahim M, Smith R III, Burghardt R and Safe S: Role of Sp proteins in regulation of vascular endothelial growth factor expression and proliferation of pancreatic cancer cells. Cancer Res 64: 6740-6749, 2004.

20. Tan NY and Khachigian LM: Sp1 phosphorylation and its regulation of gene transcription. Mol Cell Biol 29: 2483-2488, 2009.

21. Safe S and Abdelrahim M: Sp transcription factor family and its role in cancer. Eur J Cancer 41: 2438-2448, 2005.

22. Hsieh MJ, Chen JC, Yang WE, Chien SY, Chen MK,Lo YS, His YT, Chuang YC, Lin CC and Yang SF: Dehydroandrographolide inhibits oral cancer cell migration and invasion through NF-kB-, AP-1-, and SP-1-modulated matrix metalloproteinase-2 inhibition. Biochem Pharmacol 130: 10-20, 2017.

23. Zhang Y, Wang H, Liu Y, Wang C, Wang J, Long C, Guo W and Sun X: Baicalein inhibits growth of Epstein-Barr virus-positive nasopharyngeal carcinoma by repressing the activity of EBNA1 Q-promoter. Biomed Pharmacother 102: 1003-1014, 2018.

24. Zhou H, Liu Y, Wang C, Liu L, Wang H, Zhang Y, Long C and Sun X: Triptolide inhibits Epstein-Barr nuclear antigen 1 expression by increasing sensitivity of mitochondria apoptosis of nasopharyngeal carcinoma cells. J Exp Clin Cancer Res 37: $192,2018$.

25. Zhou H, Guo W, Long C, Wang H, Wang J and Sun X: Triptolide inhibits proliferation of Epstein-Barr virus-positive B lymphocytes by down-regulating expression of a viral protein LMP1 Biochem Biophys Res Commun 456: 815-820, 2015.

26. Banerjee S, Sangwan V, McGinn O, Chugh R, Dudeja V, Vickers SM and Saluja AK: Triptolide-induced cell death in pancreatic cancer is mediated by O-GlcNAc modification of transcription factor Sp1. J Biol Chem 288: 33927-33938, 2013.

27. Yao JC, Wang L, Wei D, Gong W, Hassan M, Wu TT, Mansfield P, Ajani J and Xie K: Association between expression of transcription factor Sp1 and increased vascular endothelial growth factor expression, advanced stage, and poor survival in patients with resected gastric cancer. Clin Cancer Res 10: 4109-4117, 2004.

28. Enya K, Hayashi H, Takii T, Ohoka N, Kanata S, Okamoto T and Onozaki K: The interaction with Spl and reduction in the activity of histone deacetylase 1 are critical for the constitutive gene expression of IL-1 alpha in human melanoma cells. J Leukoc Biol 83: 190-199, 2008.

29. Shin JA, Kim JJ, Choi ES, Shim JH, Ryu MH, Kwon KH, Park HM, Seo JY, Lee SY, Lim DW, et al: In vitro apoptotic effects of methanol extracts of dianthus chinensis and acalypha australis L. targeting specificity protein 1 in human oral cancer cells. Head Neck 35: 992-998, 2013.

30. Fox JT, Sakamuru S, Huang R, Teneva N, Simmons SO, Xia M, Tice RR, Austin CP and Myung K: High-throughput genotoxicity assay identifies antioxidants as inducers of DNA damage response and cell death. Proc Natl Acad Sci USA 109: 5423-5428, 2012.

31. Yu J, Liu H, Lei J, Tan W, Hu X and Zou G: Antitumor activity of chloroform fraction of Scutellaria barbata and its active constituents. Phytother Res 21: 817-822, 2007.

32. Gong WY, Zhao ZX, Liu BJ, Lu LW and Dong JC: Exploring the chemopreventive properties and perspectives of baicalin and its aglycone baicalein in solid tumors. Eur J Med Chem 126: 844-852, 2017.
33. Baumann S, Fas SC, Giaisi M, Müller WW, Merling A, Gülow K, Edler L, Krammer PH and Li-Weber M: Wogonin preferentially kills malignant lymphocytes and suppresses T-cell tumor growth by inducing PLCgamma1- and Ca2+-dependent apoptosis. Blood 111: 2354-2363, 2008.

34. Zhou QM, Wang S, Zhang H, Lu YY, Wang XF, Motoo Y and Su SB: The combination of baicalin and baicalein enhances apoptosis via the ERK/p38 MAPK pathway in human breast cancer cells. Acta Pharmacol Sin 30: 1648-1658, 2009.

35. Gao J, Morgan WA, Sanchez-Medina A and Corcoran O: The ethanol extract of Scutellaria baicalensis and the active compounds induce cell cycle arrest and apoptosis including upregulation of $\mathrm{p} 53$ and $\mathrm{Bax}$ in human lung cancer cells. Toxicol Appl Pharmacol 254: 221-228, 2011.

36. Ling Y, Chen Y, Chen P, Hui H, Song X, Lu Z, Li C, Lu N and Guo Q: Baicalein potently suppresses angiogenesis induced by vascular endothelial growth factor through the p53/Rb signaling pathway leading to G1/S cell cycle arrest. Exp Biol Med (Maywood) 236: 851-858, 2011

37. Chen $\mathrm{CH}$, Huang TS, Wong $\mathrm{CH}$, Hong CL, Tsai YH, Liang CC, Lu FJ and Chang WH: Synergistic anti-cancer effect of baicalein and silymarin on human hepatoma HepG2 Cells. Food Chem Toxicol 47: 638-644, 2009.

38. Dou J, Wang Z, Ma L, Peng B, Mao K, Li C, Su M, Zhou C and Peng G: Baicalein and baicalin inhibit colon cancer using two distinct fashions of apoptosis and senescence. Oncotarget 9: 20089-20102, 2018.

39. Tian Y, Zhen L, Bai J, Mei Y, Li Z, Lin A and Li X: Anticancer effects of baicalein in pancreatic neuroendocrine tumors in vitro and in vivo. Pancreas 46: 1076-1081, 2017.

40. Sachita K, Yu HJ, Yun JW, Lee JS and Cho SD: YM155 induces apoptosis through downregulation of specificity protein 1 and myeloid cell leukemia-1 in human oral cancer cell lines. J Oral Pathol Med 44: 785-791, 2015.

41. Cho JH, Lee RH, Jeon YJ, Shin JC, Park SM, Choi NJ, Seo KS, Yoon G, Cho SS, Kim KH, et al: Role of transcription factor Sp1 in the 4-O-methylhonokiol-mediated apoptotic effect on oral squamous cancer cells and xenograft. Int J Biochem Cell Biol 64: 287-297, 2015.

42. Druzgal CH, Chen Z, Yeh NT, Thomas GR, Ondrey FG, Duffey DC, Vilela RJ, Ende K, McCullagh L, Rudy SF, et al: A pilot study of longitudinal serum cytokine and angiogenesis factor levels as markers of therapeutic response and survival in patients with head and neck squamous cell carcinoma. Head Neck 27: 771-784, 2005

43. Bond M, Fabunmi RP, Baker AH and Newby AC: Synergistic upregulation of metalloproteinase- 9 by growth factors and inflammatory cytokines: An absolute requirement for transcription factor NF-kappa B. FEBS Lett 435: 29-34, 1998

44. Mburu YK, Egloff AM, Walker WH, Wang L, Seethala RR, van Waes $\mathrm{C}$ and Ferris RL: Chemokine receptor 7 (CCR7) gene expression is regulated by NF- $\mathrm{BB}$ and activator protein 1 (AP1) in metastatic squamous cell carcinoma of head and neck (SCCHN). J Biol Chem 287: 3581-3590, 2012.

45. Lee E, Park HR, Ji ST, Lee Y and Lee J: Baicalein attenuates astroglial activation in the 1-methyl-4-phenyl-1,2,3,4-tetrahydropyridine-induced Parkinson's disease model by downregulating the activations of nuclear factor- $\kappa \mathrm{B}, \mathrm{ERK}$, and JNK. J Neurosci Res 92: 130-139, 2014.

46. Sahu BD, Mahesh Kumar J and Sistla R: Baicalein, a bioflavonoid, prevents cisplatin-induced acute kidney injury by up-regulating antioxidant defenses and down-regulating the MAPKs and NF-кB Pathways. PloS One 10: e0134139, 2015.

47. Wan CX, Xu M, Huang SH, Wu QQ, Yuan Y, Deng W and Tang QZ: Baicalein protects against endothelial cell injury by inhibiting the TLR4/NFkB signaling pathway. Mol Med Rep 17: 3085-3091, 2018.

48. Yu X, Liu Y, Wang Y, Mao X, Zhang Y and Xia J: Baicalein induces cervical cancer apoptosis through the NF- $\kappa \mathrm{B}$ signaling pathway. Mol Med Rep 17: 5088-5094, 2018.

49. Yu X, Tang W, Yang Y, Tang L, Dai R, Pu B, Feng C and Xia J: Long noncoding RNA NKILA enhances the anti-cancer effects of baicalein in hepatocellular carcinoma via the regulation of NF- $\kappa \mathrm{B}$ signaling. Chem Biol Interactions 285: 48-58, 2018. 